\title{
Komunikasi Pemasaran Olahraga Renang
}

\author{
Dwini Hanika Reftari ${ }^{1}$, Asep Suryana ${ }^{2}$, dan Agus Setiaman ${ }^{3}$ \\ 1,2,3 Universitas Padjadjaran
}

\begin{abstract}
ABSTRAK
Komunikasi pemasaran memiliki peran penting dimana pemasaran olahraga menjadi salah satu kajian akademik yang menjelma menjadi sebuah bidang kajian yang menarik dan strategis dalam mendukung pembangunan, baik dalam pengertian pembangunan olahraga. Suatu organisasi menggunakan berbagai bentuk komunikasi pemasaran untuk mempromosikan apa yang mereka tawarkan dan mencapai tujuan finansial. Akan tetapi pada penelitian ini, organisasi PB PRSI adalah organisasi non-profit yang tujuan akhirnya tidak menghasilkan finansial. Tujuan penelitian ini adalah untuk menjelaskan strategi promosi yang dilakukan oleh organisasi PB PRSI dalam mempromosikan olahraga renang; serta untuk mengetahui alasan organisasi PB PRSI yang mengalami kendala dalam menjalankan strategi promosi olahraga renang. Penelitian ini menggunakan metode kualitatif dengan pendekatan studi kasus yang dapat mendeskripsikan, memahami, dan mengembangkan komunikasi pemasaran olahraga bagi organisasi PB PRSI. Data yang diperoleh melalui hasil wawancara dengan enam informan dari berbagai latar belakang yang berbeda-beda. Observasi dengan cara mendapatkan video serta foto berupa sponsorship yang bekerjasama dengan PB PRSI; serta studi dokumentasi. Hasil penelitian menunjukkan bahwa melaksanakan strategi promosi organisasi PB PRSI dalam mempromosikan olahraga renang di Indonesia ialah dengan berbagai macam cara mulai dari media sosial, media cetak, media televisi, serta melalui komunikasi pemasaran terpadu: berupa event. Cara mempromosikannya melalui beberapa konsep dari komunikasi pemasaran serta pemasaran olahraga seperti iklan, public relations, dan personal selling. Dalam melaksanakan strategi promosi organisasi PB PRSI terdapat beberapa kendala, diantaranya yakni fasilitas olahraga, prestasi yang sedang menurun, sponsorship, serta anggaran dana.
\end{abstract}

Kata-kata Kunci: Komunikasi pemasaran; olahraga renang; pb prsi; pemasaran olahraga; strategi promosi

\section{Marketing Communications of Swimming Sports}

\begin{abstract}
Marketing communication has an important role where sports marketing is one of the academic studies that transforms into an interesting and strategic field of study in supporting development, both in terms of sports development. An organization uses various forms of marketing communication to promote what they offer and achieve financial goals. However, in this study, the PB PRSI organization is a non-profit organization whose ultimate goal is not to produce finance. The purpose of this study is to explain the promotion strategies carried out by PB PRSI organizations in promoting swimming sports; as well as to find out the reasons for PB PRSI organizations that experienced obstacles in carrying out swimming sports promotion strategies. This study uses a qualitative method with a case study approach that can describe, understand, and develop sports marketing communication for PB PRSI organizations. Data obtained through interviews with six informants from different backgrounds. Observation by getting videos and photos in the form of sponsorships in collaboration with PB PRSI; and documentation studies. The results of the study show that implementing the PB PRSI organization's promotion strategy in promoting swimming sports in Indonesia is in various ways ranging from social media, print media, television media, and through integrated marketing communication: in the form of events. How to promote it through several concepts from sports marketing and marketing communications such as advertising, public relations, and personal selling. In implementing the promotion strategy of PB PRSI organizations there are several obstacles, including sports facilities, declining achievements, sponsorships, and budget funds.
\end{abstract}

Keywords: Marketing communications; pb prsi; promotion strategy; sport marketing; swimming

Korespondensi: Dwini Hanika Reftari, M.I.Kom. Universitas Padjadjaran. Jalan Raya Bandung-Sumedang KM. 21 Jatinangor 45363.Email: onlinedwini@gmail.com 


\section{PENDAHULUAN}

Organisasi olahraga di Indonesia merupakan salah satu pihak yang paling bertanggung jawab, karena di tangan organisasi inilah mekanisme kegiatan olahraga dirancang dan dijalankan (Lumintuarso, 2013). Pengurus Besar Persatuan Renang Seluruh Indonesia atau yang biasa disingkat dengan (PB PRSI) ialah organisasi non-profit yang mengatur kegiatan olahraga renang di Indonesia. PRSI berdiri pada tanggal 21 Maret 1951 di Jakarta dengan ketua umum pertamanya adalah Prof. dr. Poerwo Soedarmo. Di bawah kepemimpinan Prof. Poerwo, olahraga renang Indonesia sedikit demi sedikit mengalami kemajuan dan berkembang ditahun 1952.

PRSI sendiri sudah tercatat menjadi anggota resmi dari Federasi Renang Dunia atau yang biasa dikenal dengan Federation Internasionale de Nation (FINA) dan International Olympic Committee (IOC). Organisasi PB PRSI menaungi lima cabang olahraga aquatic, di antaranya renang, renang indah, polo air, renang terbuka, dan loncat indah. Pada hakikatnya organisasi PB PRSI sudah berupaya melakukan berbagai serangkaian komunikasi pemasaran olahraga melalui strategi promosi dalam mempromosikan olahraga renang di Indonesia.

Seiring berjalannya waktu dari tahun ke tahun, menurut Triady Fauzi Sidiq perkembangan olahraga renang dirasa sudah lebih banyak dan mulai meningkat, dilihat dari orang-orang yang berminat ikut olahraga renang, baik prestasi maupun hanya menjaga kebugaran dan dibuktikan dengan data yang sudah peneliti dapatkan pada kejuaraan renang antar perkumpulan se-Indonesia (KRAPSI), diikuti sebanyak 1.005 peserta dan di tahun 2016 sebanyak 1.018 peserta. Ini artinya bahwa minat masyarakat untuk mengikuti kejuaraan pada olahraga renang semakin meningkat.

Dilihat dari data skala survei Indonesia yang peneliti dapatkan, olahraga renang termasuk kedalam lima besar jenis olahraga yang paling disukai oleh publik Indonesia. Ini artinya bahwa sebenarnya olahraga renang memiliki peluang besar untuk menjadi industri olahraga modern, jika dibandingkan dengan olahraga lainnya yang ada di Indonesia, tidak termasuk olahraga sepakbola dan bulutangkis.

Menurut hemat peneliti mengapa fenomena ini muncul, dikarenakan perkembangan olahraga yang ada di Indonesia saat ini sudah menjadi ladang industri yang mampu menghasilkan keuntungan bagi cabang olahraganya itu sendiri. Pada era globalisasi ini muncul terminologi sportainment yang memberikan peneguhan bahwa olahraga bukan lagi sekedar sebuah tontonan melainkan sebuah industri hiburan (Sukarmin, 2014).

Alasan peneliti memilih organisasi PB PRSI untuk diteliti karena PB PRSI itu sendiri adalah kasus yang unik dinilai dari organisasi nonprofit yang bergerak dibidang olahraga terutama olahraga renang yang memiliki strategi promosi yang berbeda dengan organisasi olahraga lainnya, dilihat dari salah satu strateginya melalui event Festival Akuatik Indonesia 2017, dengan mempertandingkan "master swimming" sebagai salah satu cara untuk mempromosikan olahraga renang melalui event tersebut. Dimana pertandingan atau event olahraga yang ada di Indonesia, tidak ditemukan strategi promosi yang serupa dari cabang-cabang olahraga lainnya.

Keberhasilan suatu penyelenggaraan event olahraga tidak terlepas dari peran pemasaran. Sebuah event olahraga diperlukan strategi khusus yang dikenal dengan bauran pemasaran, yaitu kiat kelompok pemasaran yang digunakan untuk mencapai sasaran pemasarannya dalam pasar sasaran. Jika olahraga dikelola secara profesional dapat mendatangkan keuntungan ekonomi disamping keuntungan non ekonomi (Sukarmin, 2014).

UU Republik Indonesia nomor 3 tahun 2005 tentang sistem keolahragaan nasional, pasal 97 poin (2) menyebutkan bahwa, Industri olahraga dapat berbentuk jasa penjualan kegiatan cabang olahraga sebagai produk utama yang dikemas secara profesional yang meliputi; kejuaraan nasional dan internasional; pekan olahraga daerah wilayah, nasional, dan internasional; promosi, eksibisi, dan festival olahraga; atau kagenan, layanan informasi, dan konsultasi keolahragaan. Sedangkan menurut akademisi olahraga Ujang Sudrajat, tidak semua cabang olahraga memiliki nilai promosi yang tinggi bagi dunia usaha. Nilai bisnis yang rendah, akan menjadi penghambat utama bagi sponsor untuk memberikan bantuan terhadapnya.

Kotler dan Keller mengatakan bahwa "Marketing communications are means by which firms attempt to inform, persuade, and remind consumers - directly or indirectly 
- about the products and brands they sell". bahwa komunikasi pemasaran adalah sarana yang digunakan perusahaan dalam upaya untuk menginformasikan, membujuk, dan mengingatkan konsumen baik secara langsung maupun tidak langsung tentang produk dan merk yang mereka jual (Sarjita, 2016).

Kegiatan pemasaran wajib dimiliki oleh setiap perusahaan maupun organisasi agar dapat terus berkembang, dalam hal ini komunikasi olahraga melibatkan proses diantaranya olahraga komunikasi, dan komunikasi antara praktisi industri olahraga, organisasi, dan para pemangku kepentingan internal dan eksternal untuk mendapatkan hubungan timbal balik antara mereka (Pedersen, et, al, 2007).

Pada penelitian ini komunikasi pemasaran memiliki peran penting dimana pemasaran olahraga menjadi salah satu kajian akademik, yang menjelma menjadi sebuah bidang kajian yang menarik dan strategis dalam mendukung pembangunan, baik dalam pengertian pembangunan olahraga maupun olahraga nasional.

Perusahaan atau suatu organisasi menggunakan berbagai bentuk komunikasi pemasaran untuk mempromosikan apa yang mereka tawarkan dan mencapai tujuan finansial. Hasil yang ada pada pusat pemasaran olahraga nasional adalah lembaga yang mempunyai tugas dalam membina organisasi olahraga, seperti melakukan promosi cabang olahraga, mencari sponsor untuk menghimpun dana dan mengadakan evaluasi suatu produk industri olahraga sebelum dilempar kepasaran (Yusuf, 2011).

Akan tetapi pada penelitian ini, organisasi PB PRSI adalah organisasi non-profit yang tujuan akhirnya tidak menghasilkan finansial untuk membangun industri olahraga renang itu sendiri menurut Zoraya Perucha saat di wawancara. Mengacu pada penelitian menurut (Lumintuarso, 2013) organisasi olahraga di Indonesia memiliki aktifitas humas internal seperti komunikasi dengan pemerintahan (induk), komunikasi internal, dan pembinaan anggota yang relatif cukup baik. Hal ini dibuktikan dengan presentase pelaksanaan kegiatan yang tinggi. Namun dari aspek kegiatan eksternal seperti publisitas, penyelenggaraan event, penelitian dan sponsorship masih belum menggembirakan.

Komunikasi pemasaran dalam penelitian ini dijelaskan secara terperinci mengenai strategi promosi yang dilakukan oleh PB PRSI dalam mempromosikan olahraga renang di Indonesia. Dalam hal ini promosi adalah salah satu kegiatan yang dilakukan dari aspek komunikasi pemasaran. Promosi adalah segala bentuk komunikasi yang digunakan untuk menginformasikan (to inform), membujuk (to persuade), atau mengingatkan orang-orang tentang produk yang dihasilkan organisasi, individu maupun rumah tangga (Lestari, 2015).

Berbeda dengan promosi pada umumnya, batas pada penelitian ini ialah strategi promosi dalam hal mempromosikan olahraga renang yang diketahui PB PRSI adalah organisasi nonprofit. Maka dari itu terkait dengan hal ini, Smith (2008), mengatakan: "Promotion can be defined as the way that sport marketers communicate with consumers to inform, persuade and remind them about the features and benefits described by a sport product's positioning" (Muhamad, Sudarma, \& Sudrajat, 2016).

Dengan kata lain, promosi dapat diartikan sebagai cara atau jalan seorang pemasar dalam menyampaikan informasi, penjelasan kepada konsumen, mengenai produk-produk olahraga atau kegiatan keolahragaan. Saat mempromosikan produk atau kegiatan keolahragaan ini, tim pemasaran olahraga dituntut bukan saja memahami informasi terkait dengan produk olahraga dan kegiatan olahraga, tetapi memiliki kemampuan untuk berkomunikasi dan kemampuan untuk menyakinkan masyarakat atau calon konsumen.

Dalam hal ini, peneliti mencoba mengungkapkan fenomena olahraga dari sisi komunikasi pemasaran olahraga, dimana fenomena olahraga renang saat ini sedang mengalami perubahan dari sisi pemasaran olahraga itu sendiri, mengingat bahwa ketua umum dari organisasi PB PRSI saat ini adalah seorang pengusaha yang bergerak di bidang media televisi swasta di Indonesia. Maka dari itu promosi olahraga renang sedang gencargencarnya dilakukan oleh organisasi PB PRSI, agar masyarakat Indonesia menikmati kegiatan keolahragaan renang itu sendiri.

Penelitian ini juga dapat bermanfaat bagi organisasi dari cabang olahraga lainnya untuk mempromosikan olahraganya itu sendiri. Serta bagi ketua umum, bidang humas dan promosi PB PRSI agar lebih meningkatkan promosi olahraga renang di Indonesia. Berdasarkan 
penjelasan di atas, maka peneliti memutuskan untuk melakukan penelitian dengan judul "Komunikasi Pemasaran Olahraga Renang (Studi Kasus Pada Strategi Promosi Organisasi PB PRSI dalam Mempromosikan Olahraga Renang di Indonesia)".

Berdasarkan latar belakang yang telah diuraikan di atas, maka peneliti menetapkan fokus penelitian, yaitu: "Bagaimana komunikasi pemasaran olahraga renang melalui serangkaian strategi promosi yang dilakukan oleh organisasi PB PRSI dalam mempromosikan olahraga renang di Indonesia?"; maka dapat dijabarkan dalam bentuk pertanyaan penelitian sebagai berikut ini: (1) Bagaimana strategi promosi yang dilakukan organisasi PB PRSI dalam mempromosikan olahraga renang di Indonesia?; (2) Mengapa organisasi PB PRSI mengalami kendala dalam menjalankan strategi promosi olahraga renang di Indonesia?

Adapun tujuan dari penelitian ini adalah; (1) Menjelaskan strategi promosi yang dilakukan oleh organisasi PB PRSI dalam mempromosikan olahraga renang di Indonesia; (2) Untuk mengetahui alasan organisasi PB PRSI yang mengalami kendala dalam menjalankan startegi promosi olahraga renang di Indonesia.

\section{METODE PENELITIAN}

Tujuan dari studi kasus pada penelitian ini adalah untuk mendeskripsikan, memahami, dan mengembangkan komunikasi pemasaran olahraga bagi organisasi di PB PRSI. Pada tahap ini, alasan yang melatarbelakangi peneliti menggunakan studi kasus adalah pertama adanya upaya bidang humas dan promosi PB PRSI dalam mempromosikan olahraga renang di Indonesia melalui serangkaian strategi promosi organisasi PB PRSI dalam mempromosikan olahraga renang di Indonesia.

Secara umum studi kasus merupakan strategi yang lebih cocok bila pertanyaan suatu penelitian berkenaan dengan how (bagaimana) atau why (mengapa). Sedangkan studi kasus merupakan studi yang mendalam hanya pada satu kelompok atau peristiwa. Peristiwa yang ada pada penelitian ini ialah olahraga renang yang identik dengan olahraga elit dan mahal.

Pada penelitian ini, keunikan kasus yang diangkat ialah berawal dari organisasi PB PRSI yang melakukan serangkaian strategi promosi, salah satu strateginya melalui event
Festival Akuatik Indonesia 2017, dengan mempertandingkan "master swimming" sebagai salah satu cara untuk mempromosikan olahraga renang melalui event tersebut, dimana pertandingan atau event olahraga yang ada di Indonesia, tidak ditemukan strategi promosi yang serupa dari cabang olahraga lainnya.

Robert K. Yin, membagi penelitian studi kasus menjadi tiga tipe di antaranya; studi kasus eksplorasi yakni kasus-kasus tertentu yang diteliti secara terperinci, pengumpulan data secara mendalam baik melalui berbagai sumber informasi; studi kasus eksplanatori yakni kasuskasus tertentu yang diteliti dengan tujuan untuk memberikan pengetahuan sebab-akibat; studi kasus deskriptif dimana kasus-kasus tertentu yang akan diteliti, tujuannya untuk memberikan gambaran yang mendalam mengenai kasus tersebut, serta di dalamnya terdapat paparan konsep-konsep penelitian (Yin, 2015).

Penelitian ini mengaplikasikan studi kasus eksplorasi karena adanya keunikan kasus yang perlu diteliti secara terperinci, pengumpulan data secara mendalam baik melalui berbagai sumber informasi. Pembahasan dibuat berdasarkan berbagai sumber informasi yang berkaitan dengan komunikasi pemasaran olahraga renang melalui serangkaian strategi promosi yang dilakukan oleh organisasi PB PRSI.

Objek di dalam penelitian ini adalah bagaimana komunikasi pemasaran olahraga renang di Indonesia melalui serangkaian strategi promosi organisasi PB PRSI dalam mempromosikan olahraga renang di Indonesia. Selanjutnya subjek pada penelitian ini adalah pengurus besar persatuan renang seluruh Indonesia (PB PRSI) selaku organisasi yang melaksanakan strategi promosi dalam mempromosikan olahraga renang di Indonesia.

Pada penelitian ini, peneliti menggunakan teknik purposive sampling untuk menentukan informan kunci, yaitu dengan cara memperoleh informasi mengenai komunikasi pemasaran olahraga renang PB PRSI di Indonesia dalam hal mempromosikan olahraga renang, dimana peneliti mengambil informan berdasarkan kriteria-kriteria tertentu yang peneliti buat berdasarkan tujuan riset.

Purposive sampling adalah teknik pengambilan sumber data dengan pertimbangan tertentu. Pertimbangan tertentu ini, misalnya orang tersebut yang dianggap paling tahu tentang apa yang kita harapkan, atau 
mungkin dia sebagai penguasa sehingga akan memudahkan peneliti menjelajahi objek/situasi sosial yang akan diteliti (Sugiyono, 2012), dalam hal ini peneliti menggunakan teknik purposive sampling dengan menentukan key informant yang akan menjadi narasumber yaitu pihak yang paling bertanggung jawab serta pihak yang menjadi objek dari pelaksanaan komunikasi pemasaran olahraga renang di Indonesia dalam hal mempromosikan olahraga renang oleh PB PRSI.

Setelah melakukan pra-riset, peneliti menentukan key informant dalam penelitian ini dengan kriteria sebagai berikut: (1) Informan harus berkaitan langsung dengan proses komunikasi pemasaran olahraga renang di Indonesia dalam hal mempromosikan olahraga renang; (2) Informan harus menguasai kegiatan komunikasi dalam hal pemasaran olahraga melalui strategi promosi olahraga renang di Indonesia; (3) Informan harus menguasai pengetahuan mengenai perkembangan dunia olahraga terutama olahraga renang; (4) Informan merupakan pihak yang kompeten dalam hal komunikasi khususnya olahraga. Berdasarkan kriteria sampel di atas, maka peneliti menentukan informan awal yang paling revelan dalam penelitian ini yang dirangkum dalam tabel 1.

Peneliti juga menambahkan informan lain yang berasal dari eksternal yaitu atlet, akademisi di bidang olahraga yang juga penulis buku mengenai sport marketing, produser berita olahraga, serta CEO Agensi Manajemen Olahraga Sportinco guna memverifikasi dan mendukung keabsahan data yang didapat, informan tersebut. Data informan pendukung dirangkum pada tabel 2.

Teknik pengumpulan data adalah teknik yang digunakan dalam proses pengadaan data untuk kepentingan penelitian. Pengumpulan data adalah prosedur yang sistematis dan standar untuk memperoleh data yang diperlukan. Teknik pengumpulan data yang digunakan dalam penelitian ini adalah sebagai berikut; (1) Wawancara. Dalam penelitian ini, peneliti melakukan wawancara langsung dengan sekjen PB PRSI, bidang humas dan promosi PB PRSI, atlet renang Indonesia, produser atau wartawan olahraga, akademisi olahraga serta CEO agensi manajemen olahraga Sportinco.

Wawancara yang pertama dilakukan oleh peneliti, ialah dengan atlet renang itu sendiri. Dilaksanakan pada tanggal 19 Desember 2016, melalui jejaring media sosial direct message Instagram. Pada awalnya peneliti mewawancarai dua atlet renang yakni Triady Fauzi Sidiq dan Raina Saumi Grahana. Peneliti mewawancarai dua atlet renang ini terkait dengan fenomena apa yang sedang terjadi di dalam dunia olahraga renang. Ternyata peneliti menemukan hal baru yang ada pada dunia olahraga renang, yakni sang

Tabel 1 Informan Penelitian

\begin{tabular}{llll}
\hline No & Nama & Posisi Jabatan & Lama Bekerja \\
\hline 1. & Bapak Ali A Pratiwiri & Sekjen PB PRSI periode 2016-2020 & 2 Periode \\
2. & Ibu Zoraya Perucha & $\begin{array}{l}\text { Bidang Humas \& Promosi PB PRSI } \\
\text { periode 2016-2020 }\end{array}$ & 2 Periode \\
\hline
\end{tabular}

Sumber: Data Peneliti, 2017

Tabel 2 Informan Pendukung

\begin{tabular}{|c|c|c|c|}
\hline No & Nama & Posisi Jabatan & Lama Bekerja \\
\hline 1. & Bapak Ali A Pratiwiri & Sekjen PB PRSI periode 2016-2020 & 2 Periode \\
\hline 2. & Ibu Zoraya Perucha & $\begin{array}{l}\text { Bidang Humas \& Promosi PB PRSI } \\
\text { periode 2016-2020 }\end{array}$ & 2 Periode \\
\hline 3. & Bapak Ujang Sudrajat & Tenaga Pendidik/ Akademisi Olahraga & 20 Tahun \\
\hline 4. & Mas Agus Susanto & Produser Berita Olahraga ANTV & 12 Tahun \\
\hline
\end{tabular}

Sumber: Data Peneliti, 2017 
atlet Raina Saumi mengikuti agensi manajemen olahraga yaitu Sportinco.

Berawal dari keterkaitan agensi manajemen olahraga Sportinco muncul dalam penelitian ini. Akan tetapi Raina Saumi Grahana tidak menjadi informan kelanjutan pada penelitian ini. Sedangkan Triady Fauzi Sidiq berkelanjutan menjadi informan pada penelitian ini karena peneliti menyimpulkan bahwa kriteria yang ada pada penentuan key informants tertuju pada Triady saja. Lalu peneliti melanjutkan wawancara yang kedua pada tanggal 25 Januari 2017 dengan sekjen PB PRSI, Bapak Ali A Patiwiri yang dilakukan dikantor PB PRSI, berlokasi Wisma Bakrie 1 jalan H.R Rasuna Said. Karet Kuningan, Jakarta Selatan.

Bapak Ali diutus oleh ketua umum PB PRSI untuk diwawancarai dengan peneliti, maka dari itu wawancara dengan ketua umum diwakilkan oleh sekjen PB PRSI. Sekjen itu sendiri singkatan dari sekertaris jendral, dimana jika ketua umum sulit untuk ditemui, maka sekjen yang menggantikannya. Pada penelitian ini, peneliti mewawancarai terkait dengan perkembangan olahraga renang yang ada di Indonesia, visi dan misi dari organisasi PB PRSI, serta program kedepannya yang akan dilaksanakan oleh PB PRSI untuk mempopulerkan olahraga renang.

Selanjutnya peneliti melanjutkan wawancara yang ketiga pada tanggal 27 Januari 2017 dengan Daniel, CEO Agensi Manajemen Olahraga Sportinco. Awal pertimbangan peneliti untuk melakukan wawancara dengan Daniel ialah pernyataan yang dilontarkan oleh atlet Raina Saumi Grahana yang menyebutkan bahwa Ia mengikuti agensi manajemen olahraga. Dari situ peneliti ingin mewawancarai terkait dengan apa yang ditawarkan agensi manajemen olahraga ini dengan atlet renang. Apa dasar yang kemudian menjadikan agensi manajemen olahraga ini menarik atlet renang atau olahraga renang.

Wawancara yang keempat ialah dengan humas dan promosi PB PRSI yakni Ibu Zoraya Perucha, wawancara ini dilaksanakan dua kali dengan rentan waktu yang berbeda yakni pada tanggal 31 Januari 2017, serta 22 April 2017. Lokasinya pun berbeda, pada tanggal 31 Januari 2017 berlokasi di Wisma Bakrie 2 lantai 7 jalan H.R Rasuna Said, Jakarta Selatan. Serta pada tanggal 22 April 2017 di stadium Jakabaring aquatic, Palembang, Sumatera Selatan. Dalam penelitian ini, Ibu Zoraya Perucha memiliki andil yang cukup besar. Karena dari beliau, peneliti menanyakan beberapa pertanyaan yang penting dan berkaitan dengan komunikasi pemasaran olahraga renang di Indonesia (studi kasus pada strategi promosi organisasi PB PRSI dalam mempopulerkan olahraga renang). Inti dari wawancara pada penelitian ini, ada pada Ibu Zoraya Perucha selaku bidang humas dan promosi PB PRSI.

Wawancara kelima peneliti lakukan dengan akademisi olahraga yakni Bapak Ujang Sudrajat, dimana menurut peneliti beliau cocok untuk menjelaskan terkait olahraga renang dari sisi akademisi olahraga. Wawancara dilakukan di Universitas Islam 45 Bekasi (UNISMA) pascasarjana ilmu keolahragaan lantai 3 pada tanggal 21 Juni 2017. Peneliti mewawancarai beliau terkait dengan keabsahan data yang peneliti dapatkan melalui serangkaian wawancara dengan Ibu Zoraya Perucha sebagai bidang humas dan promosi PB PRSI, serta idealnya suatu organisasi olahraga dalam mempromosikan atau mempopulerkan olahraga renang itu sendiri.

Selanjutnya peneliti melakukan wawancara yang keenam dengan wartawan yang merangkap sebagai produser olahraga ANTV. Wawancara itu sendiri dilaksanakan pada tanggal 20 Juli 2017 di Epicentrum ANTV, lalu dilanjutkan dengan mengirim email kepada peneliti. Peneliti melakukan wawancara lantaran ingin melihat bagaimana dari sisi media televisi memberitakan olahraga renang dalam suatu program olahraga, perkembangan olahraga renang dari kacamata seorang wartawan olahraga. Serta harapan seorang wartawan atau produser olahraga terhadap olahraga renang itu sendiri.

Dalam melakukan wawancara dengan informan baik informan penelitian maupun informan pendukung, peneliti dibantu oleh beberapa peralatan pendukung seperti alat perekam (voice recorder) dan catatan-catatan untuk melancarkan segala proses wawancara serta untuk memperkecil kemungkinan bagi peneliti kehilangan data; (2) Observasi, Observasi yang dilakukan pada penelitian ini, yaitu pertama mewawancarai seluruh informan penelitian maupun informan pendukung dengan cara merekam menggunakan alat perekam yang tersedia dalam handphone atau telephone genggam. Setelah itu peneliti pindahkan file tersebut kedalam laptop, agar tidak kehilangan 
data atau memperkecil kemungkinan bagi peneliti kehilangan data. Setelah melakukan observasi dengan cara merekam, peneliti tidak ketinggalan dengan melakukan beberapa catatan penting dari hasil wawancara tersebut.

Selanjutnya peneliti mengobservasi dengan cara mendapatkan video asli (tidak berupa editan atau di cut perbincangannya) yang berasal dari seorang cameramen ANTV yakni kak Ilham pada saat event Festival Akuatik Indonesia 2017 Palembang dilaksanakan. Video tersebut berupa Press Conference event Festival Akuatik Indonesia 2017 di Palembang yang dilaksanakan oleh PB PRSI. Bagaimana ketua umum memberikan sambutan dan memaparkan kegiatan dari event Festival Akuatik Indonesia 2017 itu seperti apa, lalu sambutan dari Gubernur Sumatera Selatan serta apresiasi kepada PB PRSI.

Pada kesempatan observasi terakhir peneliti melakukan sesi foto berupa sponsorship yang bekerjasama pada event Festival Akuatik Indonesia 2017, foto dengan para narasumber, dan foto suasana pada saat event Festival Akuatik Indonesia 2017 berlangsung; (3) Studi Dokumentasi, Selama proses penelitian, peneliti juga mengumpulkan dokumen-dokumen kualitatif. Dokumen ini bisa berupa dokumen publik (seperti koran, makalah, laporan kantor). Setiap data-data yang diperoleh, dikumpulkan, dan digunakan sebagai bahan penunjang didalam penelitian.

Peneliti mengumpulkan informasi melalui dokumen-dokumen yang dimiliki oleh humas dan promosi PB PRSI seperti foto dokumentasi, Press Release event Festival Akuatik Indonesia 2017, Susunan acara pada event Festival Akuatik Indonesia 2017, Sejarah berdirinya organisasi PB PRSI, ketua umum PB PRSI dari masa ke masa.

Pada penelitian kualitatif, data diperoleh dan dianalisis disaat pengumpulan data berlagsung dan ketika pengumpulan data selesai didalam periode waktu tertentu. Miles dan Huberman menyatakan bahwa aktivitas dalam analisis data kualitatif dilakukan secara interaktif dan berlangsung secara terus menerus sampai tuntas, sehingga datanya sudah jenuh (Sugiyono, 2013) .

Pada penelitian ini, peneliti menggunakan langkah-langkah teknik analisis data (Yin, 2011), yang membagi teknik analisis data menjadi lima tahapan, diantaranya compiling, disassembling, reassembling, interpreting, concluding (Damanhuri, 2016). Pada tahapan yang pertama yaitu compiling berperan untuk mengkopilasi data yang ditemukan pada saat di lapangan, berupa data hasil wawancara, observasi serta studi dokumentasi. Tahapan pertama ini dilakukan dengan cara mengelompokkan dan menyusun data sesuai kebutuhan, tujuan, dan kemudahan dalam proses pelaksanaan analisis data.

Tahapan yang kedua yaitu disassembling atau pembongkaran. Peneliti dalam tahapan ini melakukan pengamatan kembali terhadap datadata hasil temuan yang ada di dalam penelitian dan telah diorganisir. Tahapan yang ketiga yakni reassembling merupakan penyusunan kembali dan mengkombinasikan kembali data-data yang sesuai dengan kebutuhan peneliti.

Sementara tahapan yang keempat yaitu interpreting merupakan tahapan yang mana peneliti memiliki kemampuan untuk menginterpretasikan data temuan hasil penelitian. Interpretasi tersebut berlandaskan kepada pengetahuan peneliti serta tambahan data yang ditemukannya di lapangan penelitian.

Dalam hal ini, kajian teori, konseptual dan penelitian terdahulu memiliki peran sebagai dasar pengetahuan peneliti tentang fenomena yang ditelitinya. Tahapan terakhir yaitu concluding atau penutup, dalam penelitian peneliti yang telah mendapatkan data dan kemudian diolah atau dianalisis olehnya yang selanjutnya membuatkan sebuah kesimpulan dan penyelesaian di dalam penelitian.

Penelitian kualitatif menghadapi persoalan penting mengenai pengujian keabsahan dari hasil penelitian itu sendiri. Dalam penelitian ini dibangun sebuah mekanisme untuk mengatasi keraguan terhadap hasil penelitian kualitatif. Sehubungan dengan hal tersebut, Moleong mencoba membangun teknik pengujian keabsahan yang diberi nama teknik pemeriksaan (Bungin, 2007) sebagai berikut; (1) Triangulasi dengan Sumber Data, Pada penelitian ini triangulasi dengan sumber data dilakukan dengan membandingkan dan mengecek baik derajat kepercayaan suatu informasi yang diperoleh melalui waktu dan cara yang berbeda dalam metode kualitatif yang dilakukan; (1) membandingkan data hasil pengamatan dengan hasil wawancara.

Dalam penelitian ini hasil pengamatan dan hasil wawancara terbilang cukup relevan baik 
apa yang diucapkan oleh informan dengan data yang peneliti dapat dari hasil pengamatan, selanjutnya; (2) membandingkan keadaan dan perspektif seseorang dengan berbagai pendapat dan pandangan orang lain seperti rakyat biasa, orang yang berpendidikan menengah atau tinggi, orang berada dan orang pemerintahan.

Pada penelitian ini membandingkan perspektif seseorang dengan berbagai pendapat dan pandangan orang lain yang berasal dari seseorang akademisi olahraga serta CEO Agensi Manajemen Olahraga Sportinco, yang terakhir ialah; (3) membandingkan hasil wawancara dengan isi suatu dokumen yang berkaitan.

Di antaranya hasil wawancara mengenai event Festival Akuatik Indonesia 2017 dengan dokumen yang peneliti dapat dari bidang humas dan promosi PB PRSI terkait dengan event Festival Akuatik Indonesia 2017. Pada dasarnya triangulasi sumber data juga memberi kesempatan untuk dilakukannya hal-hal sebagai berikut: (1) penilaian hasil penelitian dilakukan oleh responden, (2) mengoreksi kekeliruan oleh sumber data, (3) menyediakan tambahan informasi secara sukarela, (4) memasukkan informan dalam kancah penelitian, (5) menilai kecukupan menyeluruh data yang dikumpulkan.

Peneliti juga melakukan triangulasi sumber menggunakan triangulasi narasumber dengan cara mengeksplorasi untuk mencari kebenaran data dari berbagai sumber yang memiliki keterkaitan. Pada penelitian ini, sumber-sumber tersebut berasal dari pihak yang mengamati perkembangan dunia olahraga terutama olahraga renang yakni Akademisi Olahraga, CEO Agensi Manajemen Olahraga Sportinco, serta pihak yang mengikuti kegiatan PB PRSI dalam hal mempromosikan olahraga renang yakni produser atau wartawan olahraga.

Penelitian ini dilakukan yang pertama di kantor PB PRSI yang berlokasi di Wisma Bakrie 1 dan Wisma Bakrie 2 yakni kantor kehumasan PB PRSI, jalan H.R Rasuna Said RT 01/RW 05, Karet Kuningan, Kecamatan Setiabudi, Kota Jakarta Selatan. DKI Jakarta. 12940. Serta yang kedua yakni Jakabaring Aquatic Stadium, Palembang, Sumatera Selatan. Waktu penelitian di lapangan dimulai pada bulan Desember 2016.

\section{HASIL DAN PEMBAHASAN}

Berdasarkan hasil temuan penelitian yang telah dijabarkan di atas, maka strategi promosi yang dilakukan oleh PB PRSI di antaranya melalui media sosial, media cetak, media televisi, serta komunikasi pemasaran terpadu; melalui event. Maka strategi promosi adalah perencanaan, implementasi, dan pengendalian komunikasi dari suatu organisasi kepada para konsumen dan sasaran lainnya, sehingga fungsi promosi dalam bauran pemasaran adalah untuk mencapai berbagai tujuan komunikasi dengan setiap konsumen.

Tanggung jawab pemasaran yang penting adalah merencanakan dan mengkoordinasi strategi promosi terpadu dan memilih strategi untuk komponen-komponen promosi. Menurut (Muhamad, Sudarma, \& Sudrajat, 2016) bentuk kegiatan promosi yang dimanfaatkan dalam pemasaran olahraga diantaranya: iklan; penjualan individu (personal selling) serta; public relations.

Pada penelitian ini jika dikaitkan dengan bentuk kegiatan promosi yang dimanfaatkan dalam pemasaran olahraga diantaranya melalui iklan, personal selling, dan public relations dari berbagai aspek, mulai media sosial, media cetak, media televisi serta komunikasi pemasaran terpadu; melalui event. Jika membahas mengenai media televisi sebagai salah satu strategi promosi yang dilakukan oleh organisasi PB PRSI, maka media komunikasi televisi memiliki posisi yang istimewa bagi masyarakat (Manoppo, 2012).

Melihat besarnya daya tarik televisi, maka tidak mengherankan bila media ini merupakan media primadona bagi advertiser untuk mempromosikan produknya seperti kegiatan yang dilakukan oleh organisasi PB PRSI yakni, memberitakan mengenai olahraga renang serta pertandingan-pertandingan renang yang diselenggarakan oleh PB PRSI, melalui siaran televisi TV ONE dalam acara Kabar Arena. (1) Public relations. Pada penelitian ini, menunjukkan hasil bahwa bidang humas dan promosi dalam organisasi PB PRSI, melakukan berbagai strategi promosi yang dilakukan. Diantaranya dengan promosi melalui media sosial, media cetak, media televisi.

Tugas dari bidang humas dan promosi PB PRSI adalah memperkenalkan event pertandingan, memperkenalkan atlit renang agar dikenal oleh masyarakat Indonesia, ini sejalan dengan bentuk-bentuk promosi pemasaran olahraga yang menyebutkan bahwa kegiatan promosi dari Hubungan Masyarakat 
(Humas) atau Public relations bermaksud untuk membangun citra atau imej tim, atlit, produk, atau perusahaan yang baik dihadapan masyarakat atau mitra olahraga.

Hal itu perlu dilakukan karena dengan citra positif dapat meningkatkan partisipasi masyarakat dalam olahraga, dukungan masyarakat pada olahraga dan kemitraan dengan tim perusahaan. Menurut penelitian terdahulu (Lumintuarso, 2013) aspek pokok kegiatan humas dan pemasaran, terdapat perbedaan kinerja yang jelas. Organisasi olahraga di Indonesia memiliki aktifitas humas internal seperti komunikasi dengan pemerintah (induk), komunikasi internal serta pembinaan anggota yang relative cukup baik. Namun dari aspek kegiatan eksternal seperti publisitas, penyelenggaraan event, penelitian dan sponsorship tidak menggembirakan.

Akan tetapi, ini dibuktikan dengan kegiatan humas didalam organisasi PB PRSI, dilihat dari aspek kegiatan eksternal sudah melakukan publisitas, penyelenggaraan event dan sponsorship dengan baik. Namun demikian, Thomas L Harris, menyatakan peranan humas dijabarkan menjadi "pencils" yang hampir mirip dengan bauran promosi (promotion mix) yaitu formula PASP (publications, advertising, sales promotions dan personal selling). Setiap fungsi dan tugas humas adalah menyelenggarakan publikasi atau menyebarluaskan informasi melalui berbagai media tentang aktivitas atau kegiatan perusahaan atau organisasi yang pantas untuk diketahui oleh publik (Ari, Dewi, 2018).

Pada penelitian ini, organisasi PB PRSI melakukan publisitas sebagai bentuk strategi promosi, di antaranya menerbitkan press release dari berbagai acara yang diselenggarakan oleh PB PRSI. Menciptakan berita dilakukan melalui press release, newsletter, dan bulletin dan hal lain yang mengacu pada teknik penulisan $5 \mathrm{~W}$ $+1 \mathrm{H}$ (Who, What, Where, When, Why dan How) dengan sistematika penulisan "piramida terbalik" yang paling penting menjadi lead sedangkan intro yang kurang penting diletakkan ditengah batang berita (Susianto, 2015).

Jika dilihat pada studi dokumentasi press release yang peneliti dapatkan dari bidang humas dan promosi PB PRSI, sudah menunjukkan teknik penulisan dengan benar, serta informasi yang disampaikan sudah memenuhi kebutuhan akan informasi dari olahraga renang itu sendiri. (2) Iklan. Pada penelitian ini, menunjukkan hasil bahwa strategi promosi yang ada didalam organisasi PB PRSI, melakukan iklan melalui komunikasi pemasaran terpadu berupa event. Dalam bauran promosi (promotion mix) dikenal empat teknik promosi untuk pemasaran,

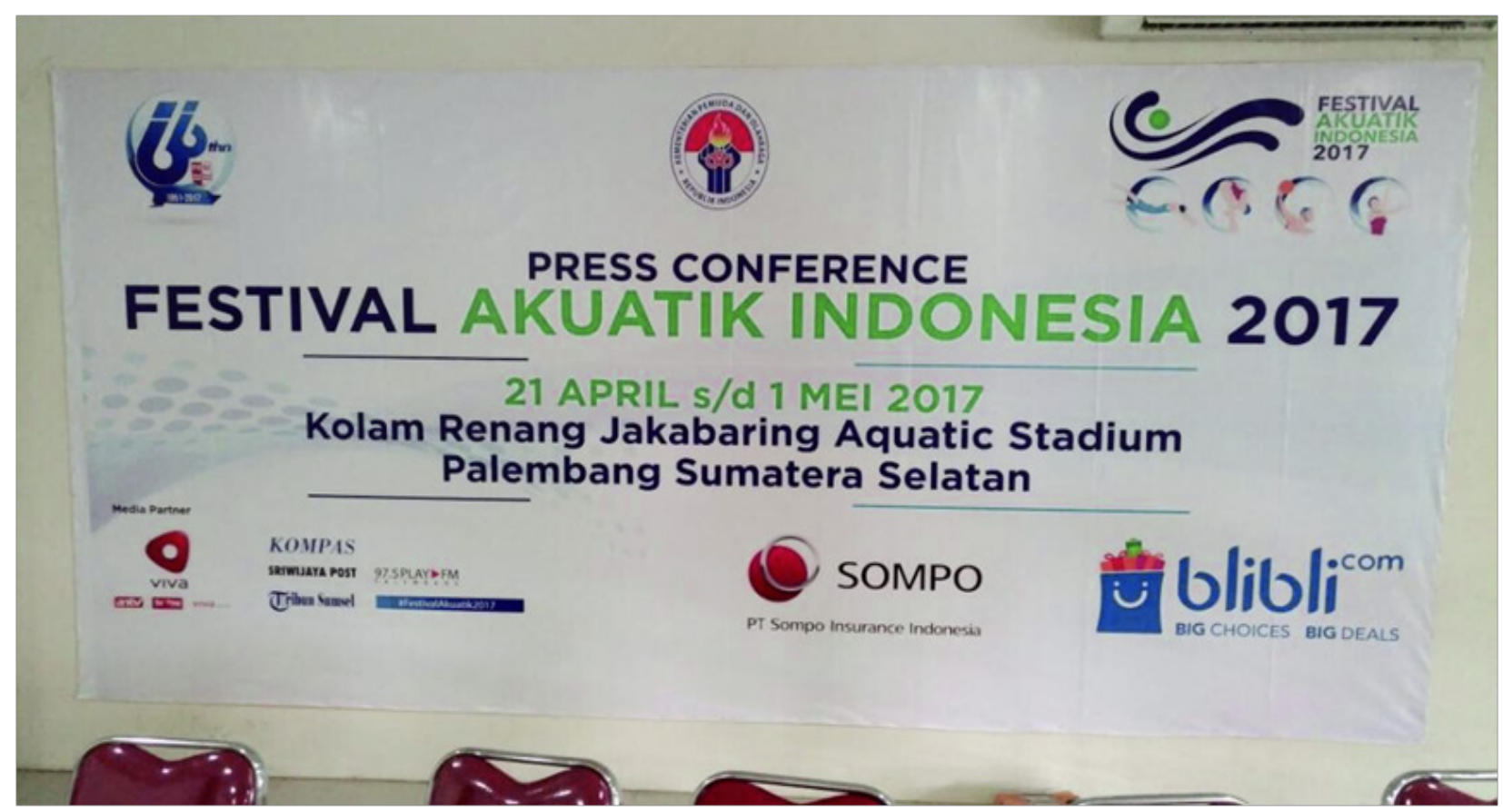

Sumber: Foto Pribadi Peneliti, 2017

Gambar 1 Baliho Pertandingan Renang di Palembang 
yakni: iklan, personal selling, publikasi, dan exhibition. Iklan adalah cara promosi yang sering digunakan dalam pemasaran komersial. Iklan dapat dilakukan melalui media, antara lain media elektronik, media cetak, serta media luar ruangan (baliho, papan reklame, poster, spanduk, dan lain-lainnya (Dharmawansyah, Cangara, et, al, 2014).

Keterkaitannya dengan penelitian ini ialah iklan yang dilakukan PB PRSI dalam menyelenggarakan suatu event yang bertajuk Festival Akuatik Indonesia 2017 di Palembang, Sumatera Selatan. Saat itu iklan yang dilakukan oleh PB PRSI di antaranya melalui media sosial serta baliho yang ada dibeberapa titik di Palembang, Sumatera Selatan. Jika iklan yang dilakukan oleh PB PRSI melalui media sosial maka, itu sudah jauh lebih efektif. Hal ini ditunjang dari pernyataan bahwa sebuah produk atau jasa bisa saja menjadi jauh lebih efektif apabila dipromosikan oleh pengguna di media sosial. Sedangkan baliho tersebut berisikan mengenai tanggal pelaksanaan, tempat penyelenggaraan, dan icon dari Festival Akuatik Indonesia itu sendiri.

Banyak yang mengatakan bahwa kegiatan promosi identik dengan dana yang dimiliki oleh suatu organisasi. Semakin besar dana yang dimiliki oleh suatu perusahaan umumnya akan menghasilkan promosi yang juga sangat gencar. Namun dana bukanlah segala-galanya. Dana yang terbatas dapat diatasi dengan inovasi yang lebih cerdas dan tepat. Dalam hal ini, organisasi PB PRSI sudah melakukan kegiatan promosinya dengan ketentuan konsep yang diusung pada penelitian ini yang pertama ialah iklan.

Salah satu aspek yang berkembang dari marketing atau pemasaran pada era media sosial adalah iklan (advertising). Iklan, menurut The American Marketing Association, diartikan sebagai pengumuman atau pesan persuasive dalam suatu waktu atau ruang menggunakan media massa oleh institusi bisnis, organisasi nonprofit, pemerintah maupun individu dengan maksud menginformasikan dan atau membujuk khalayak terhadap barang, jasa, organisasi, atau ide-ide sebagai sarana target pemasaran atau audiensi (Nasrullah, 2017). Kehadiran media sosial memberikan alternatif pilihan bagaimana praktik pemasaran pada era digital ini bisa berubah dari iklan berbayar menjadi iklan berdasarkan pengalaman pengguna yang cenderung berbiaya kecil dan terkadang tanpa biaya sama sekali.

(3) Personal selling. Kegiatan promosi yang ketiga ialah melalui Personal selling. Pada penelitian ini, bentuk dari personal selling itu sendiri berupa kerjasama sponsorship yakni suatu kegiatan olahraga yang bisa menjalin kerjasama dengan lembaga usaha atau pihak lain yang memiliki kepentingan usaha atau kepentingan kuat dalam pengembangan kegiatan olahraga. Setiap ada event, bidang humas dan promosi mendapat kerjaan tambahan dari ketua umum, berupa membantu dari segi sponsor untuk memudahkan biaya.

Jika dilihat dari observasi peneliti di lapangan, bentuk kerjasama sponsorship dalam event pertandingan renang, sudah ada peningkatan. Ditambahkan dengan hasil penelitian bahwa PB PRSI sudah mempromosikan olahraga renang dari mulut ke mulut (word of mouth). Ini artinya personal selling sudah dilakukan oleh bidang humas dan promosi PB PRSI yang diketuai oleh Ibu Zoraya Perucha. Sponsorhip yang bekerjasama pada event Festival Akuatik Indonesia 2017 ditunjukkan dalam gambar 2.

Aaron Smith memberikan penjelasan detil, bahwa ada dua bentuk penjualan individual (personal selling) yakni sponsorship dan endorsement. Sponsorship suatu kegiatan
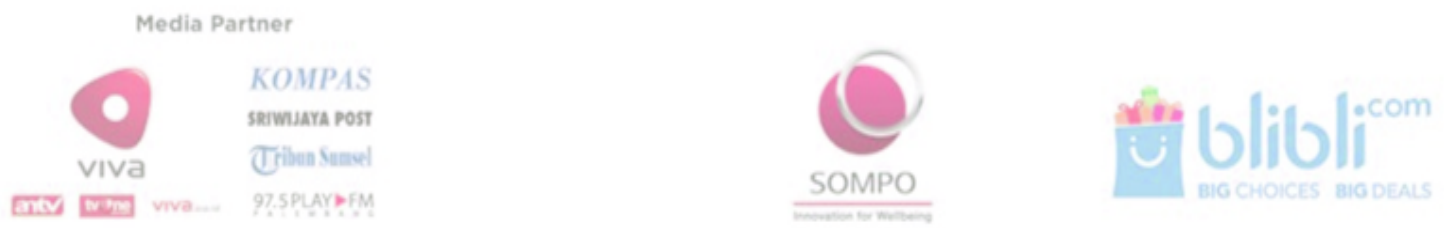

Sumber: Dokumen Press Release PB PRSI, 2017

Gambar 2 Media Partner Acara Festival Akuatik 2017 
olahraga bisa menjalin kerjasama dengan lembaga usaha atau pihak lain yang memiliki kepentingan usaha atau kepentingan kuat dalam pengembangan kegiatan olahraga. Sedangkan endorsement proses pemanfaatan selebritis atau duta budaya atau tokoh masyarakat yang bisa memainkan peran untuk turut serta dalam mempromosikan kegiatan olahraga. Seorang public figure memiliki potensi kuat untuk bisa memberikan keyakinan dan menyakinkan kepada masyarakat mengenai produk olahraga yang ditawarkan (Muhamad, Sudarma, \& Sudrajat, 2016).

Menurut pendapat peneliti, strategi promosi dari organisasi PB PRSI sudah berjalan dengan baik, artinya sudah ada perubahan dalam mempromosikan olahraga renang di Indonesia, akan tetapi sosialisasi atau promosi atau pendidikan olahraga renang memang sudah dilakukan khususnya di lembaga pendidikan formal. Sementara untuk promosi olahraga dalam konteks industri olahraga renang, kiranya, belum maksimal. Hal itu, tampak dalam kaitannya masih terbatasnya partisipasi masyarakat dalam penyelenggaraan kegiatan olahraga renang. Maksud dari partisipasi olahraga itu, baik dalam pengertian keikutsertaan sebagai atlet atau pelaku kegiatan olahraga, maupun menjadi sponsor dan penikmat kegiatan olahraga.

Gambar 3 menjelaskan mengenai model dari strategi promosi PB PRSI yang dilakukan, diantaranya ada empat yakni melalui media sosial, media televisi, media cetak serta komunikasi pemasaran terpadu: event. Alur penjelasan dari gambar keempat sebagai berikut, strategi promosi olahraga renang melalui media sosial, media televisi serta media cetak dilakukan oleh public relations dan personal selling dari organisasi PB PRSI itu sendiri. Lalu komunikasi pemasaran terpadu: melalui event Festival Akuatik Indonesia 2017 yang dilakukan oleh organisasi PB PRSI merupakan salah satu bentuk promosi dari pemasaran olahraga melalui iklan, dimana organisasi PB PRSI melakukan iklan dengan menggunakan baliho, dan banner dalam setiap pertandingan tersebut. Dalam hal ini semua aspek yang ada didalam gambar tersebut memiliki kaitan yang erat dan alur strategi promosi yang terus menerus terjadi dalam organisasi PB PRSI.

Pada pertanyaan kedua yakni, berdasarkan hasil temuan penelitian yang telah dijabarkan diatas, maka kendala yang dialami oleh organisasi PB PRSI dalam melakukan strategi promosi olahraga renang di Indonesia ialah berupa fasilitas olahraga, prestasi, sponsorship, serta anggaran dana. Berbicara mengenai sponsorship yang menjadi kendala dalam mempromosikan olahraga renang, dikarenakan tidak ada tayangan langsung di televisi dan juga berita di media massa. Padahal sebenarnya

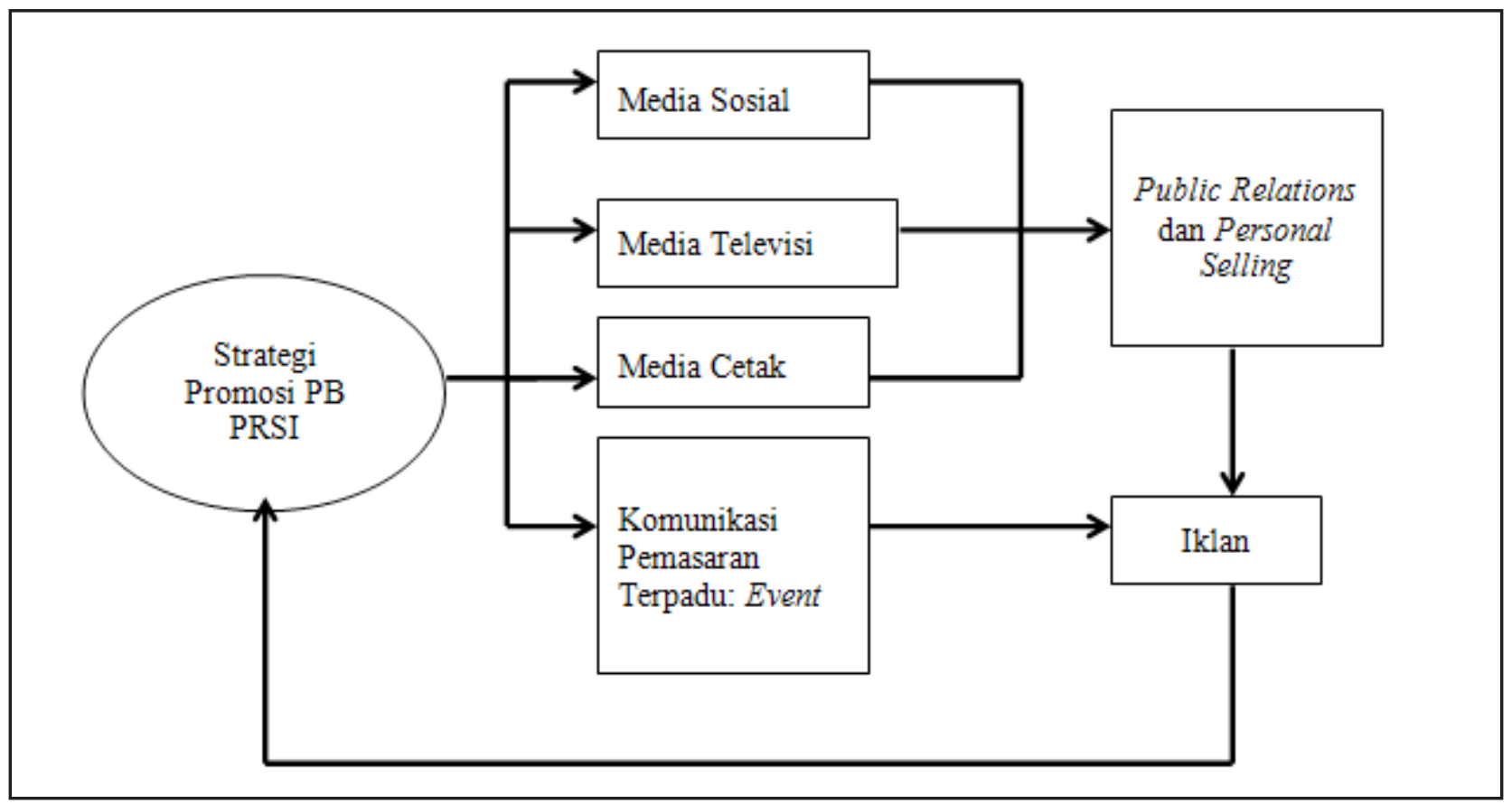

Sumber: Data Peneliti, 2017 
sudah banyak berita yang menanyangkan olahraga renang akan tetapi berita tersebut hanya pada saat event-event besar saja.

Faktor yang lainnya yaitu suatu olahraga kekurangan sponsor hal yang paling mendasar ialah efetivitas komunikasi atau pemasaran olahraga. Ini adalah hal mendasar dalam dunia usaha. Setiap penyelenggara layanan olahraga, akan dihadapkan pada kompetitor yang ketat dan padat. Karena itu, layanan dan komunikasi keolahragaan tidak bisa sambil lalu. Menurut (Lumintuarso, 2013) sponsorship merupakan faktor yang paling rawan dan lemah dalam organisasi olahraga. Secara kumulatif sangat sedikit induk organisasi yang dapat menarik sponsor kedalam kegiatan organisasi.

Hal ini sangat kontradiktif dibanding dengan perkembangan olahraga internasional dimana setiap induk organisasi memiliki sponsorship yang mendatangkan banyak keuntungan bagi kegiatan olahraga. Anggaran dana didalam suatu organisasi olahraga nonprofit, akan sering membahas mengenai dana jika ingin menyelenggarakan suatu event bertaraf nasional maupun Internasional. Organisasi PB PRSI mendapatkan dana dari Kemenpora, Ketua Umum, dan juga Mitra Kerja PB PRSI. Disini peneliti mengindikasikan bahwa sebenarnya untuk dana mempromosikan olahraga renang pun tidak ada. Maka dari itu, ini adalah salah satu faktor kendala yang serius jika menginginkan olahraga renang menjadi olahraga yang populer di Indonesia.
Namun berbeda dengan pernyataan triangulasi narasumber yang peneliti lakukan, menyebutkan bahwa sebenarnya kendala dalam mempromosikan olahraga renang ada dalam tiga tahapan, yaitu Products (produk); Place (tempat); Price (Harga); Promotion (promosi). Kekurangan yang ada pada organisasi PB PRSI ialah, mementingkan bagian Promotion (promosi) saja, tidak pada empat elemen dasar pemasaran.

Maka seharusnya organisasi PB PRSI melihat empat elemen dasar pemasaran, Products (produk) harus menjadi olahraga publik; Place (tempat) tempat berenang harus mudah dan dapat diakses oleh banyak orang; Price (Harga) jadikan olahraga renang sebagai olahraga populer yaitu murah; sedangkan Promotion (promosi) memang sudah digerakkan oleh organisasi PB PRSI.

Dengan demikian, sebenarnya dari empat elemen pemasaran tersebut, promosi adalah elemen yang memiliki keterkitan dengan perencanaan komunikasi, karena sebuah produk yang ingin dipasarkan memerlukan promosi. Sedangkan promosi memerlukan strategi dalam perencanaan komunikasi. Dalam kegiatan promosi sering muncul anggapan keliru, yakni pengeluaran biaya untuk promosi dinilai sebagai pemborosan, padahal biaya yang dikeluarkan untuk promosi harus dinilai sebagai investasi.

Gambar 4 merupakan gambaran model dari penjelasan mengenai kendala yang dialami oleh organisasi PB PRSI dalam melaksanakan

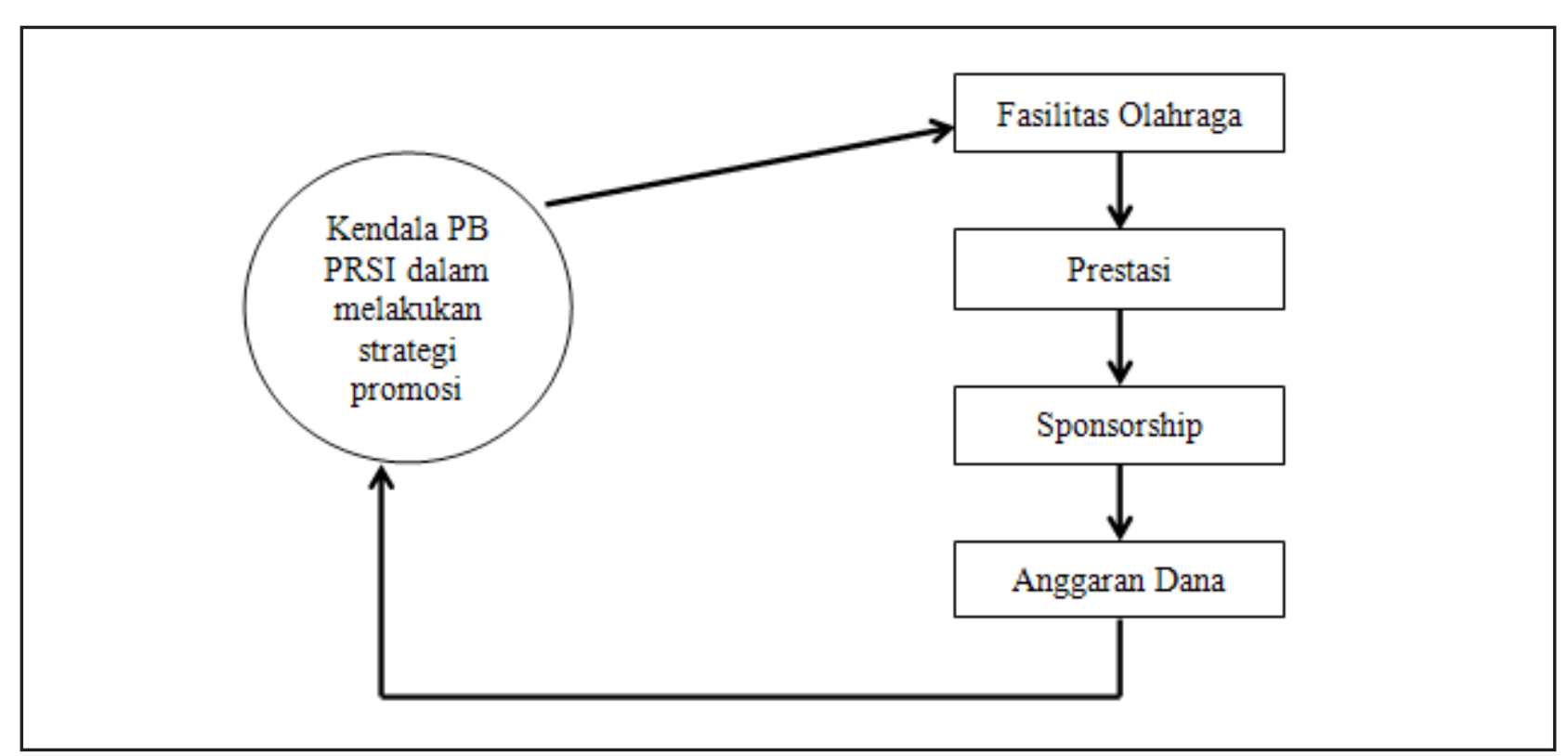

Sumber: Data Peneliti, 2017 
strategi promosi olahraga renang di Indonesia. Salah satunya terletak pada fasilitas olahraga renang yang menjadi titik kendala dalam mempromosikan olahraga renang, karena olahraga renang identik dengan olahraga elit dan mahal.

\section{SIMPULAN}

Simpulan yang didapat dari penelitian yang berjudul "Komunikasi Pemasaran Olahraga Renang (Studi Kasus Pada Strategi Promosi Organisasi PB PRSI dalam Mempromosikan Olahraga Renang di Indonesia)" adalah; (1) Melaksanakan strategi promosi organisasi PB PRSI dalam mempromosikan olahraga renang di Indonesia ialah dengan berbagai macam cara mulai dari media sosial, media cetak, media televisi, serta melalui komunikasi pemasaran terpadu: berupa event. Hal ini menunjukkan bahwa strategi promosi organisasi PB PRSI sudah maksimal dilakukan. Cara mempromosikannya melalui beberapa konsep dari komunikasi pemasaran serta pemasaran olahraga seperti iklan, public relations, dan personal selling. Dalam hal ini semua unsur strategi promosi organisasi PB PRSI dijalankan dengan baik; (2) Dalam melaksanakan strategi promosi organisasi PB PRSI terdapat beberapa kendala, di antaranya yakni fasilitas olahraga, prestasi yang sedang menurun, sponsorship, serta anggaran dana. Hal ini membuat organisasi PB PRSI, melaksanakan strategi promosi melalui media-media yang memang bekerjasama dengan organisasi PB PRSI.

Adapun saran yang peneliti berikan berdasarkan hasil penelitian ini, maka saran yang diberikan oleh peneliti adalah; (1) Sebaiknya strategi promosi organisasi PB PRSI dalam mempromosikan olahraga renang di Indonesia, melakukan kerjasama dengan beberapa stakeholder yang terkait dengan pengembangan olahraga renang itu sendiri, agar terciptanya olahraga renang yang dekat dengan masyarakat; (2) Dalam hal kendala untuk melakukan strategi promosi PB PRSI perlu adanya pertimbangan dalam hal empat elemen dasar dari pemasaran, yakni Products (produk); Place (tempat); Price (Harga); Promotion (promosi). Organisasi PB PRSI, hanya menjalankan elemen dasar pada Promotion (promosi) saja.

\section{DAFTAR PUSTAKA}

Ari, A. M. \& Dewi, M.. (2018). Strategi komunikasi kehumasan dinas pariwisata kepemudaan dan olahraga kabupaten batang dalam mengkampanyekan program roadshow pariwisata 2017. Naskah Publikasi: Universitas Islam Indonesia.

Bungin, B. (2007). Penelitian kualitatif: komunikasi, ekonomi, kebijakan publik, dan ilmu sosial lainnya (Vol. 2). Jakarta: Kencana Prenada Media Group.

Damanhuri, P. (2016). Implikatur percakapan dalam kontak interpersonal orangtua terhadap anak. Jurnal Seminar Nasional Prasasti (Pragmantik: Sastra dan Linguistik.

Dharmawansyah, S., Cangara, H., \& Sultan, M. I. (2014). Strategi promosi dalam meningkatkan jumlah mahasiswa pada politeknik negeri media kreatif makassar. Jurnal Komunikasi KAREBA, Vol. 3, No 4 Oktober - Desember.

Lestari, S. P. (2015). Hubungan komunikasi pemasaran dan promosi dengan keputusan memilih jasa layanan kesehatan. Jurnal Interaksi, Vol 4 No 2, Juli 2015: 139-147.

Lumintuarso, R. (2013). Humas dan pemasaran olahraga di indonesia. Jurnal KONI JUARA Vol 1 No 1. Januari-April 2013.

Manoppo, I. SL. (2012). Komunikasi pemasaran tayangan olahraga yang mengandung kekerasan: studi kasus tpi fighting championships. Tesis Perpustakaan Universitas Indonesia.

Muhamad, M., Sudarma, M., \& Sudrajat, U. (2016). Sport marketing: memasarkan dan mengembangkan industri olahraga. Yogyakarta: Laksitas.

Nasrullah, R. (2017). Media sosial: perspektif komunikasi, budaya, dan sosioteknologi (vol. Iii). (N. S. Nurbaya, ed.) Bandung: Simbiosa Rekatama Media.

Pedersen, P. M., Laucella, P. C., Miloch, K. S., \& Fielding, L. W. (2007). The juxtaposition of sport and communication: defining the field of sport communication. Department of Kinesiology, Indiana University: E. 7th St., HPER 112, Bloomington, IN 47405, USA. Int. J. Sport Management and Marketing, Vol. 2, No. 3, 2007. 
Sarjita. (2016). Komunikasi pemasaran dalam menghadapi persaingan pasar. JBMA Vol III, No 1, Maret. ISSN: 2252-5483.

Sugiyono. (2012). Metode penelitian kuantitatif dan kualitatif. Bandung: Alfabeta.

Sukarmin, Y. (2014). Pemasaran olahraga melalui berbagai event olahraga. Jurnal pendidikan kesehatan dan rekreasi. Artikel Universitas Negeri Yogyakarta.

Susianto, L. (2015). Strategi public relations dalam menciptakan brand awareness produk selang air pt cahaya elang mas pada masyarakat. Universitas Bina Nusantara.

Yin, R. K. (2015). Studi kasus: desain dan metode. (m. d. mudzakir, trans.) Jakarta: Rajawali Press.

Yusuf, H. M. (2011). Mencermati manajemen pembangunan olahraga nasional. Jurnal Ilmiah SPIRIT, ISSN; 1411-8319, Vol. 11 No. 1 Tahun 2011. 